\title{
The Effect of Demographic Factors on Consumer Purchase Intention in Buying Television Set in Kathmandu Valley: An Empirical Study
}

\author{
Bharat Rai \\ Lecturer, Nepal Commerce Campus, T.U.
}

\begin{abstract}
The main objective of the research is to identify the impact of demographic factors on purchase intention. The study examine whether there is any significant differences on consumers' purchase intention of television across gender, age groups and education level. Primary data has been used in the study. The structured questionnaire has been used for collection of primary data. Convenient sampling technique has been used to collect information from the respondents and 394 respondents have been taken from customers buying Television in Kathmandu. The sampling location for the research has been allocated in show room, colleges and houses in Kathmandu. Age, gender and level of education have been taken as independent variables and purchase intention has been taken as dependent variable. Percentage has been used to analyze the purchase intention of respondents; independent sample t-test and ANOVA Test have been used to analyze the collected data and to draw valid conclusions by using SPSS. The result of independent sample t-test showed that there is no significant difference on purchase intention between male and female in buying television in Nepalese market. The result of ANOVA Test showed that there is no significant difference on purchase intention among different age groups. But the result of ANOVA Test showed that there is significant difference on purchase intention among different level of education.
\end{abstract}

Key Words: Purchase Intention, Age, Gender, Level of Education.

\section{Introduction}

Intention to buy is linked to consumer behavior, expectations and attitudes. The purchasing behavior is a key point for customers to view and assess the particular product. Under the influence of demand or perceived quality and value, the decision to purchase can be modified. Therefore, customers are influenced during the procurement process by internal or external reasons (Gogoi, 2013). Customers are always of the opinion that purchasing with a low cost, clear packaging and unknown product is a high risk since they do not trust the quality of these goods (Gogoi, 2013).

Engel et al. (1995) present the most accepted model of decision making on consumer purchases. This model divides the decision process for consumer purchases into five stages: (1) question identification, (2) knowledge quest, (3) alternative assessment, (4) purchasing decision, and (5) post-purchase actions. It can be seen as a purchasing impulse action. Partially designed purchase means buyers only agree on a product category and specification before purchasing a product, and labels and styles are later decided in the store. Fully planned purchases mean consumers decide which product and brand to buy before entering the store. 
Kotler (2003) argues that human behaviors and uncertain circumstances influence the intention to buy. Individual attitudes include personal preferences towards others and obedience to the expectations of others and unpredictable situations mean that consumers change their intention to buy because a situation appears, for example, when the price is higher than expected (Dodds et al., 1991). Customer intention to buy is considered a subjective tendency towards a commodity and can be an important metric for forecasting consumer behavior (Fishbein and Ajzen, 1975). Zeithaml (1988) uses buying intended for purchase and considered to be purchasing as measuring items to measure purchasing intention.

Purchase decision is a behavior of a buyer that how he/she thinks about any particular product and what may comes in his/her mind first about it and what would he think or do when he/she purchases the same product of the same brand. There may be negative or positive impacts on that particular product and there is strong tendency for him to react based on their past actions. The individual is likely to report his/ her habit rather than intention when responding to the intention (Warsaw and Davis, 1985). Despite issues, purchase intention is an important construct of consumer behavior (Kotler and Armstrong, 2010).

\section{Literature Review}

\section{Age}

Age is frequently used segmentation variable for market (Hawkins et al. 2007; Kotler and Keller, 2006; Peter and Olson, 2008). Age is constantly used with other demographic factors like gender, income, and race while conducting research on consumer behavior (Kimand Kim 2004). Kurtz andBoone (2006) described that age is influencing factor when it comes to purchasing an automobile and in making the choice of a particular model, they found that the young consumers in different ages have different behavior and they also found that the nineteen years old consumer may behave differently with a twenty five years old consumer. For example, some young consumers are more concerned on the labeled products than other young consumers.

Daneshvary and Schower (2000) think buying intention has a relationship with demographic factors such as age. Younger consumers are more significant to influence buying intention, according to previous research. It might be because the younger consumers are more open to experience and are less concerned with prices. So, they will try to decide to make easier decision and intend to purchase something in return. Summers et al. (2006) found that Malaysian customers ' growing age will reduce the effect of age on buying intention. Consequently, consumers aged 17-21 are more likely to have an effect on the intention to buy. Furthermore, they found that some of the respondents agreed that their age factors made them think about buying leather clothing. Khan et al. (2012) found that the different age groups have little effect on the intent to buy brands. Mo and Wong (2012) argued that age influences the buying intention of consumers interested in automobile purchases. This research shows that younger consumers with lower incomes are more likely to buy an automobile than older consumers with more income. In addition, the younger consumers are more inclined to buy an automobile than older consumers. In addition, Jain and Sharma (2012) conducted other similar types of research work, arguing that consumers of different age groups have different attitudes towards brands and the intention to purchase various fast-moving goods. Madahi and Sukati (2012) conducted another research, confirming that the younger consumers are more important in influencing buying intention on consumer label products. When customer age increases the effect of age on intention to buy is high. Similarly, Karbala and Harimukti (2012) performed other similar types of research work, and they found that the age groups of people influence the intention to buy goods in Toimoi shop. The age of household private label consumers is likely a factor influencing the proneness of private label brands. Older customers typically have more shopping experience than the younger ones. Whereas younger consumers may select brand by simple heuristics, older consumers may have their own sophisticated choice processes (Richardson et al, 1996). It seems that the older consumers are more familiar with private label brands.

Cole and Balsubramanian (1993) found that younger consumers would not like to spend more money on purchasing national brands because their brand loyalty is weaker than older consumers and suggested 
that the age of customers has a significant influence on their brand loyalty. On the other hand, younger shoppers might be more images oriented and not familiar with private label brands. Younger shoppers can ultimately be inclined to spend their money on domestic brand products (Sethuraman and Cole, 1999). Recently, Lii and Hung (2003) have reported that the age variable has no impact on the purchasing intention of the storebrands. The impact of age in store brands is therefore unclear.Through the literature review above, we may infer that the young people display the intention to purchase branded goods and vehicles rather than the old age and the rise in people's age decrease the intention to purchase them. The various age groups have different purchasing intention towards the different product categories. So, for buying ofautomobiles and other shopping items young age group people have more purchase intention.

\section{Gender}

Sex is another demographic factor that has been explored to examine its impact on consumer buying behavior, as it relates to product categories. An investigation shows that music has more effect on females in restaurants than on males (Wilson, 2003). Likewise, different studies showed that men are more risk taking than women and they are more reliance on themselves to make purchase decision than women (Syed, 2003). The gender effect depends on some factors. For example, females are more concerned about those kinds of products that are directly related to the house because, as housewives, they are more concerned about the quality of the products compared with men. Label, brands and price thus have an impact on the intention of consumers to buy (Ahasanul et al.,2006). Ang et al. (2001) conducted a research on the motivation of consumers to purchase counterfeits or pirated goods in Singapore and they found that gender and income of consumers influenced their attitude towards predicting the purchase intention of consumers. Specially, males and lower income consumers have a high intention to purchase pirated goods such as music CDs. Daneshvary and Schower (2000) believed that purchase intention has a relationship with demographic factors like gender. They found that purchase intention is influenced across the gender. The female customers are more concerned about those kinds of products that are directly related to house because as housewives, the quality of the products is more important for them compared to men. Gender positively influence on purchase intention and the female more significantly influence on purchase intention. It can be because females are more influenced by friends and classmates and other colleagues. Daneshvary and Schower (2000) found that purchase intention has a relationship with demographic factors like age, gender, profession and education. Summers et al. (2006) notes that the consumer's purchasing intention is not influenced by the gender.There is similar level of purpose for transactions between male and female customers. We found that buying organic foods for women would probably cost more than men if the organic foods in Malaysia weren't too expensive and more affordable.

The research also explained that "the intention to buy organic products has been heavily influenced by the purchase-value perception on non-organic product and the belief in the product's safety and health aspect. The gender effect depends on some factors. Females are more concerned about those kinds of home appliances products; they are more concerned about the quality of their products. Mo and Wong (2012) found that gender of consumers influence their purchase intention by moderating their level of income. It means the purchase intention is influenced by gender. Another similar type of research was conducted by Khan et al. (2012) and they also found that both male and female have shown the equal knowledge about brand and purchase intention. There is no significant difference between male and female for showing the purchase intention. Behavioral intention of the female customers about the product is slightly higher than the male customers. Moreover, other research has been done by Jain and Sharma (2012) and they confirmed that there is significant difference between male and female attitude to purchase intention. Authors agreed that the gender influence on the purchase intention of different fast moving consumer goods. Same type of research has conducted by Madahi and Sukati (2012) and they concluded that gender positively affects purchase intention and the female customers significantly influence the purchase intention. Karbala and Harimukti (2012) had done the similar type of research as well, and they found that there is significant 
Silver Jubilee Issue - 2019

difference between men and women for purchase intention in Toimoi store.

This work has shown that the Toimoi store offers more psychologically female shopping than the male and female goods. Based on the above review of the literature, it is concluded that gender can influence the intention to purchase. There is significant difference between male and female customers on purchase intention because purchase intention of female customers is more affected by reference groups such as friends, colleagues and classmates.

\section{Level of Education}

Fisher et al. (2012) found that the most significant findings in intention to buy green product is education. Based on previous research, it is concluded that higher-educated consumers are more knowledgeable of green goods and know the benefits of green products (Roslin et al., 2017). Do Paco et al. (2009found that the level of education influences in the purchase intention for the green products buying. Straughan and Robert (1999)found that those with a higher the level of education were more likely to exhibit environmentally friendly behaviors, whereas Laroche et al. (2001) found that there is no significant difference in purchase intention according to level of education.Omar et al. (2016) reported that the degree of consumer awareness and purchasing intention has a significant relationship in the Malaysian purchase of organic foods. Kumar and Kumar (2019) found that less informed customers were firmly in agreement on taking advice while others were moderately in agreement on this. It was also found that educated consumers were much aware to buy the durable goods and take the buying decision independently.

Past studies showed that education level was also identified as a significant factor influencing consumer attitudes towards buying organic foods. Bio food consumers tend to be more highly educated than non-organic consumers according to Storstad and Bjorkhaug (2003).

Higher educated consumers have been found to be more interested in buying organic food than those with less education (Magnusson et al., 2001; Zepeda and Li, 2007; Dettmann and Dimitri, 2007). This is because people withhigher education require more information on organic production methods and processes (Wier and Calverley, 2002) and it also found that there is more willing to pay a premium for organic food (Jolly and Norris 1991; Wandel and Bugge,1997). Conference paper of Che and Ahmad (2018) concluded that the level of education is concerned with the green personal care product purchase intention in Malasia.

\section{Research Objective}

The objective of the research isto examine whether there is any significant differences on consumers' purchase intention of televisionacross gender, age groups and education level.

\section{Theoretical Framework}

After reviewing different researches concerning purchase intention of consumers, the own creation of the theoretical framework has been formed. It was believed that the framework consists of main factors that have impact on purchase intention.

This study designed the framework in consideration to three main factors that have impact on consumer purchase intention towards television buying.

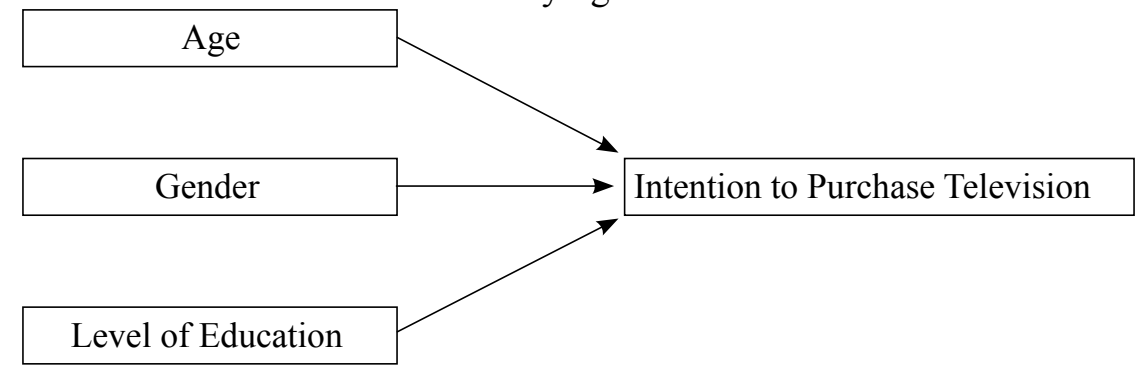




\section{Research hypothesis}

H1: There is significant difference on purchase intention between male and female towards television buying.

H2: There is significant difference on purchase intention across the age groups towards television buying.

H3: There is significant difference on purchase intention across the level of education towards television buying.

\section{Research Methodology}

Research methodology covers the type of research design used for undertaking population and sample, sampling process, source of data, data collection procedures and analytical tools used to analyze the data and develop the relationship between factors influencing purchase intention.

The research design of the study is descriptive based on primary data. Using survey methodology, structured questionnaires has been administered to obtain responses from television purchaser in Nepalese market. Primary data has been used from television purchaser in Nepalese market. The population in the study is the consumers who will purchase the Television in Nepalese market and who are residents of Kathmandu valley. Convenient sampling method has been used in this study. The sampling location for the research has been allocated in show room, colleges and houses in Kathmandu. The sample size of the study is the 394. Collected data has been analyzed by using percentage. Independent sample t-test has been used to identify the significant difference on purchase intention between male and female towards television buying and one way ANOVA has been used to identify the significant difference on purchase intention across the age and level of education groups towards television buying.

\section{Results}

The collected data has been analyzed by descriptive statistics and inferential statistics.

Table 1

Demographic information by Gender

\begin{tabular}{ccc}
\hline & Frequency & Percentage \\
\hline Male & 239 & 60.7 \\
Female & 155 & 39.3 \\
Total & 394 & 100 \\
\hline
\end{tabular}

The result of the demographic profile by gender shows that the respondents $239(60.7 \%)$ and 155 $(39.3 \%)$ are males and females respectively. These percentages reflect the structure of balanced mix of entire gender population.

Table 2

Demographic information by Age group

\begin{tabular}{ccc}
\hline Age group & Frequency & Percentage \\
\hline $16-25$ & 190 & 48.2 \\
$26-35$ & 90 & 22.8 \\
$36-45$ & 64 & 16.3 \\
Above 45 & 50 & 12.7 \\
Total & 394 & 100 \\
\hline
\end{tabular}

The results of the demographic profile by age groups show that majority of the respondents are at the age bracket of 16 to 25 (48.2\%), followed by 26 to $35(22.8 \%), 36$ to $45(16.3 \%)$ and $45+(12.7 \%)$ 
Silver Jubilee Issue - 2019

correspondingly.

Table 3

Demographic information by Level of Education

\begin{tabular}{ccc}
\hline Level of Education & Frequency & Percent \\
\hline Master & 229 & 58.2 \\
M.Phil & 103 & 26.1 \\
Ph.D. & 62 & 15.7 \\
Total & 394 & 100.0 \\
\hline
\end{tabular}

The results of the demographic profile by level of education shows that the respondents are at the Master, 229 (58.2\%), M.Phil, 103 (26.1\%), and Ph.D. 62 (15.7\%) correspondingly.

\section{Independent Sample t-test}

Independent sample t-test is used for testing the significance of two group means. For this we need two variables. One quantitative variable the group of which means are being tested and others categorical variable that defines the two groups of interest.

Table 4

Independent samples t-test on purchase intention across gender

\begin{tabular}{|c|c|c|c|c|c|c|}
\hline \multirow{4}{*}{$\begin{array}{l}\text { Purchase } \\
\text { intention }\end{array}$} & \multirow{4}{*}{$\begin{array}{l}\text { Equal variances assumed } \\
\text { Equal variances not } \\
\text { assumed }\end{array}$} & \multicolumn{4}{|c|}{$\begin{array}{c}\text { Levene's Test for Equality of } \\
\text { Variances }\end{array}$} & \multirow{3}{*}{$\begin{array}{c}\text { t-test for Equality of } \\
\text { Means } \\
\text { Sig. (2-tailed) } \\
0.790\end{array}$} \\
\hline & & $\mathrm{F}$ & Sig. & $\mathrm{t}$ & $\mathrm{df}$ & \\
\hline & & .017 & 0.895 & -0.267 & 392 & \\
\hline & & & & 0.266 & 324.826 & 0.791 \\
\hline
\end{tabular}

The result of Leven's test for equality of variance indicates that there is no significant difference in variance of responses towards the purchase intention. Since, $P$ value $(0.895)$ is greater than $0.05(p>0.05)$ since it is insignificant. So, the alternate hypothesis is rejected.

The result has not supported the hypothesis (H1) that there is significant difference on purchase intention between male and female. So, it is concluded that there is no significant difference in the purchase intention of consumer's for buying television set in Nepalese market across the gender.

\section{Analysis of Variance (ANOVA) Test}

ANOVA is a technique for detecting relationships between quantitative variable (dependent) and one or more categorical variables (independent). It enables us to test for significant difference between two or more groups as well as look at the interaction of two independent variables with the dependent variables.

Table 5

Purchase Intention across the different age groups

\begin{tabular}{lccccc}
\hline & Sum of Squares & df & Mean Square & F & Sig. \\
\hline Between Groups & 0.439 & 3 & 0.146 & 0.491 & 0.688 \\
Within Groups & 116.093 & 390 & 0.298 & & \\
Total & 116.532 & 393 & & & \\
\hline
\end{tabular}


The above table ANOVA test showsthe insignificant $\mathrm{p}$ value 0.688 which is greater than $0.05(\mathrm{p}>0.05)$. Hence, the alternate hypothesis is rejected. The result has not supported the hypothesis (H2) that there is significant difference on purchase intention among different age groups. This means, there is no significance difference on the purchase intention of television buying across the age groups. So, it is concluded that there is no significant difference in purchase intention of customers across the age groups for buying television sets in the Nepalese market. Due to no significant difference for buying the television among the different age groups further Post Hoc analysis should not be carried out for group comparison.

Table 6

Purchase Intention across the different level of Education

\begin{tabular}{lccccc}
\hline & Sum of Squares & df & Mean Square & F & Sig. \\
\hline Between Groups & 145.739 & 14 & 10.410 & 263.126 & .000 \\
Within Groups & 14.994 & 379 & .040 & & \\
Total & 160.734 & 393 & & & \\
\hline
\end{tabular}

The above table ANOVA test shows the $\mathrm{p}$ value $=0.000$, which is less than $(\mathrm{p}<0.05)$. Hence, the alternate hypothesis is accepted and null hypothesis is rejected. The result has supported the hypothesis (H3) that there is significant difference on purchase intention among different level of education. So, it is concluded that there is significant difference in purchase intention of customers across the level of education for buying television sets in the Nepalese market. Due to significant difference for buying the television among the different level of education further Post Hoc analysis should be carried out for group comparison.

Table 7

\section{Multiple Comparisons \\ Dependent Variable: PI}

\section{LSD}

(I) level of

education

Master

M.Phil

Ph.D.

M.Phil
(J) level of

$$
\text { education }
$$

M.Phil

P.hd

Master

Ph.D

Master
Mean Difference

(I-J)

.48826*

$1.27409^{*}$

$-.48826^{*}$

$.78583 *$

$-1.27409^{*}$

$-.78583^{*}$
Std.

Error

.07213

.09772

.07213

.08704

.09772

.08704
Sig.

.000

.000

.000

.000

.000

.000
95\% Confidence Interval

Lower Bound Upper Bound

.3465

.6301

1.4662

$-.3465$

.9570

$-.6301$

$-1.0820$

$-1.4662$

$-.9570$

*. The mean difference is significant at the 0.05 level.

From the above table the $\mathrm{p}$ value of group comparisons is less than 0.05 or $(\mathrm{p}>0.05)$. It means the effect of level of education on purchase intention is significant. However, post hoc test indicates that the means of Masters, M.Phil and Ph.D. holders have significant difference in purchase intention. So, it is concluded that there is significant difference among the different level of education groups in purchase intention in the buying of television set.

\section{Conclusion}

In this research, three important demographic variables were chosen to investigate their effect on the purchase intention. Age, gender and level of education are taken as independent variables to examine the effect on purchase intention for buying television in Nepalese market. Independent sample t-testshowed that there is no significant difference between male and female in purchase intention in buying television. The ANOVA Test showed that there is no significant difference purchase intention in buying television 
across the age groups. But, ANOVA Test showed that there is significant difference on purchase intention for buying television set in Nepalese market.

\section{References}

Ahasanul, H., Khatibi, A. and Sadeghzadeh, J. (2006). Identifying Potentiality Online Sales In Malaysia: A Study On Customer Relationships Online Shopping. Journal of applied business research, 22 (4).

Ang, S. H., Cheng, P. S., Lim, E. A. C., and Tambyah, S. K. (2001). Spot the difference: consumer responses towards counterfeits. Journal of Consumer Marketing, 18(3), 219-235.

Che In, F. and Ahmad, A. (2018). The effect of demographic factors on consumer intention to purchase green personal care products. Conference paper on Religion, Social Sciences and Technological Education, in Malasia.

Cole, C.A. and Balasubramanian, S.K. (1993). Age difference in consumers' search for information: public policy implication. Journal of Consumer Research. 20(6), 157-169.

Daneshvary, R. and Schwer, K. (2000). "The association endorsement and consumer intention to purchase". Journal of consumer marketing, 17.

Dettmann, R.L. and Dimitri, C. (2007). Who's buying organic vegetables? Demographic characteristics of US consumers. Journal of Food Distribution Research 16(1), 49-62.

Do Paco, A., Raposo, M. and Walter, F.L. (2009). Identifying the green consumer: A segmentation study. Journal of Targeting, Measurement and Analysis for Marketing 17 (1), 17-25.

Dodds, W.B, Monroe, K. B. and Grewal, D. (1991). Effects of price, brands and store information on buyers' product evaluation. Journal for Marketing Research, 28, 307-19.

Enjel, J. F., Blackwell, R. D., and Miniard, P. W. (1995). Consumer behavior. New york. What do you want to be when it grows up? big and strong?. Journal of advertising research.

Fishbein, M, and Aizen, I. (1975). Brief, Attitude, intention and behavior: an introduction to theory and research, MA, USA: Addition-Wesley.

Fishbein, M. (1975). "Attitude and the prediction of behavior", in Fishbein, M. (Ed.), Attitude Theory and Measurement, John Wiley and Sons, New York, NY, pp.

Fisher, C., Bashyal, S. and Bachman, B. (2012). Demographic impacts on environmentally friendly purchase behaviors. Journal of Targeting, Measurement and Analysis for Marketing, Volume 20, Issue $3-4$, pp 172-184.

Gogoi, B. (2013). Study of antecedents of purchase intention and its effect on brand loyalty of private label brand of apparel. International Journal of Sales and Marketing, 3(2), 73-86.

Hawkins, D. L., Mothersbaught, D. L., and Best, R. J. (2007). Consumer Behavior: Building Marketing Strategy (10th ed.). New York, NY: McGraw-Hill Irwin.

Jain, K. and Sharma, P. (2012). Brand awareness and customer preference for FMCG products in rural market: An empirical study on the rural market of Garwal region,VSRD. International Journal ofBusiness and Management Research: 8 (2), 434-443.

Jolly, D. A. and Norris, K. (1991). Marketing prospects for organic and pesticide-free produce. American Journal of Alternative Agriculture 6(4), 174-179.

Karbala, Y. and Harimukti, H. (2012). Analyzing the factors that affecting consumer's purchasing intention in Toimoi store' in Indonesia. 2nd international conference on business management andbehavioral science, 13-14.

Khan, I., Ghauri, T., and Mazeed, S. (2012). Impact of brand related attributes on purchase intention of customers. A study about the customers of Punjab, Pakistan. Interdisciplinary journal of contemporary research in business.

Kim, E. Y., and Kim, Y. K. (2004). Predicting online purchase intentions for clothing products. European Journal of Marketing, 38(7), 883-897.

Kotler, P. and Armstrong, G. (2010). "Principles of Marketing", New Jersey: Pearson Prentice Hall.

Kotler, P. and Keller, K.L. (2006).Marketing management. New Jersey. Person education, Inc. 
Kotler, P. (2003). Marketing Management (11th ed.). New Jersey: Prentice Hall.

Kumar, R. and Kumar, R. (2019). Impact of various demographic factors on consumer behavior - an empirical study of electronic products in rural Himachal, Indian. journal of economics and business, 19 (1), 109-127.

Kurtz, D. L. and Boone, L. E. (2006). Principles of Marketing, Thomson South-Western, P-656.

Laroche, M., Bergeron, J. and Forleo, G.B. (2001). Targeting consumers who are willing to pay more for environmentally friendly products. Journal of Consumer Marketing 18 (6): 503-520.

Lii, Y.S. and Hung, S.Y. (2003). A study of the relationship between consumer characteristics and store brand purchase. Commerce and management quarterly.

Lii, Y.S. and Hung, S.Y. (2003). A study of the relationship between consumer characteristics and store brand purchase. Commerce and management quarterly.

Madahi, A. and Sukati, I, (2012). The effect of external factors on purchase intention among young generation in Malsia. International Business Research; 5, (8).

Magnusson, M. K., Arvola, A., Hurstiulla, K., Åberg, L.L. and Sjodenper, O. (2001). Attitudes towards organic foods among Swedish consumers. British Food Journal 103(3), 209-226.

Mo, H. F., and Wong, W.M. (2012). Purchase Intention of Consumers for an Automobile in the United States; A Hieratical Regression Model. Journal of Fashion Marketing and Management, 12 (3), 294307.

Omar, N. A., Nazri, M. A., Osman, L.H. and Ahmad, M.S. (2016). The effect of demographic factors on consumer intention to purchase organic products in the Klang Valley: An empirical study. Malaysian Journal of Society and Space, 12(2), 68 - 82.

Peter, J. P. and Olson, J. C., (2008). Consumer Behavior and Marketing Strategy, Singapore, McGraw- Hill/ Irwin.

Richardson, H., Paul S., Alan S. Dick and Arun K. J. (1996). Household store brand proneness: a framework. Journal of Retailing. 72(2),159-185.

Roslin, A. R., Zuraidah, S., Thoo, A. C., Mohd, S. M. A. and Mohd, H. A. H. (2017). E-WOM Review Adoption: Consumers' Demographic Profile Influence on Green Purchase Intention. IOP Conf. Series: Materials Science and Engineering, 215.

Sethuraman, R. and Cole, C. (1999). Factors influencing the price premiums that consumers pay for national brands over store brands. Journal of Product and Brand Management. 8(4), 340-351.

Storstad, O. and Bjorkhaug, H. (2003). Foundations of production and consumption of organic food in Norway: Common attitudes among farmers and consumers. Agriculture and Human Values, 20, 15163.

Straughan, R. D. and Roberts, J. A. (1999). Environmental segmentation alternatives: A look at green consumer behavior in the new millennium. Journal of Consumer Marketing 16 (6): 558-575.

Summers, T., Belleau, B., and Xu, Y. (2006). Predicting purchase intention of a controversial luxury apparel product. Journal of fashion Marketing Management. 10(4), 405-419.

Syed, A. (2003). Digital divide and purchase intention: why demographic psychology matters. Journal of ecology psychology. 24(23).

Wandel, M. and Bugge, A. (1997). Environmental concern in consumer evaluation of food quality. Food Quality and Preference 8(1), 19-26.

Warshaw, P. R. and Davis, F. D. (1985). Disentangling behavioral intention and behavioral expectation. Journal of Experimental Social Psychology, 21(3), 213-228.

Wier, M. and Calverley, C. (2002). Market potential for organic foods in Europe. British Food Journal 104(1),45-62.

Zeithaml, V. (1988). Consumer perceptions of price, quality and value: A means-end model and synthesis of evidence. Journal of Marketing, 52, 2-22.

Zepeda, L. and Li, J. (2007). Characteristics of organic food shoppers. Journal of Agricultural and Applied Economics 39(1), 17-28. 
